\title{
Evaluating a Technique used to Measure Environmental Performance within Agriculture - Case Studies
}

\author{
$\mathrm{K}$ A Lewis and J Tzilivakis \\ Department of Environmental Sciences, University of Hertfordshire \\ College Lane, Hatfield, Herts, AL10 9AB, UK
}

From:

Dr K A Lewis

Department of Environmental Sciences

University of Hertfordshire

College Lane

Hatfield

Herts

AL10 9AB, UK

Tel: 44 (0) 1707284582

Fax: 44 (0) 1707285258

Email:k.a.lewis@herts.ac.uk 


\title{
Evaluating a Technique used to Measure Environmental Performance within Agriculture - Case Studies
}

\author{
K A Lewis and J Tzilivakis \\ Department of Environmental Sciences, University of Hertfordshire
}

\begin{abstract}
A methodology has been developed which can be used to assess the environmental performance of a farm. The computer-based system, known as EMA, utilises a checklist auditing process based on both quantitative and qualitative data and looks, holistically, at the farm assessing a wide range of farming activities including crop production, crop protection, resource and waste management, livestock husbandry and conservation. The system relies on the use of eco-ratings which are activity based performance indices derived by comparing actual farm practices with what is perceived to be site specific best practice. The system utilises a similar approach to that used in standard environmental management systems, such as ISO14001, by providing a scale for performance measurement to allow monitoring of improvements and progress, and to permit performance highs and lows to be identified.

The system has recently under-gone piloting and evaluation in-house, on-farm and in collaboration with a major UK Retailer, Safeway Stores plc. This paper describes this process and presents the findings in the form of case studies. A brief description of the system is included for completeness.
\end{abstract}

\section{INTRODUCTION}

Over the past three years a computer based system to enable sound environmental performance by the farming industry has been developed. This system, known as EMA, has been described in detail elsewhere (Lewis et al., 1996; Tucker et al., 1996) and so only a summary is provided here. The system aims to prevent or minimise the negative environmental impacts arising from agriculture at source and to encourage and harness the positive effects. As described by Newbold et al. (1997) EMA adopts, on an informal basis, the same principals as standard environmental management systems such as ISO14001 (1994) aiming to assess current performance, encourage improvements, identify significant effects and determine estimates of emissions in the form of an inventory. Performance is measured using a scoring system to compare actual practices with what is perceived to be best practice and deriving indices, known as eco-ratings, on a pre-defined scale.

There are many agricultural activities which significantly impact on the environment including the improper use of fertilisers and pesticides, unsustainable soil practices, intensive livestock management, changes in land use, energy use, resource utilisation and farmland conservation (Skinner et al., 1997). There are a wide range of methods for assessing the environmental impact arising from these practices but the majority of these are concerned with a single impact or activity only. For example, Reus \& Pak (1993) consider the environmental impact of agricultural pesticide use as does Hornsby (1992) and many researchers are studying the fate of nitrates in the environment (e.g. AAB, 1992). By considering just a single activity these systems can not completely take into account environmental trade-offs, that is where quality improvements in one area may be off-set by damage to another. This can be illustrated with the action of placing a lid on a slurry tank. Whilst ammonia emissions may be reduced, the nitrogen content of the slurry will be higher and so the risk of nitrate leaching may also be higher. Consequently, such single activity assessment techniques do not allow the best practicable environmental option to be identified. The holistic approach of EMA considers a broad range of farming activities, allowing whole farm assessments and providing an integrated approach to environmental protection within agriculture.

\section{THE ECO-RATING SYSTEM}

Performance indices known as eco-ratings have been derived by comparing actual farm practices with site specific best practices. Individual activities are scored depending upon the amount of hazard to the environment they pose. Scores are artificial numbers attributed to particular events or actions (Lewis et al., 1997a) and are numerical representations of the relative importance of an environmental impact (or some other) event. The approach aims to reflect the potential impact whilst conveying complex information regarding the hazards posed by particular actions in an easily understood manner. Within EMA, the eco-ratings span a positive-negative scale. Positive values represent an environmental gain, negative values represent environmental damage. The zero point, therefore, indicates a neutral activity. For example, the planting of new hedgerows would represent 
an environmental gain and a positive eco-rating. Removing hedgerows is an environmental loss and the eco-rating would be negative. However, sound and environmentally responsible management of hedgerows would receive an eco-rating close to zero.

The system user should seek to modify practices such that eco-ratings are as high as possible. However, best practice does not necessarily mean that no environmental impact will occur. In many instances, such as with pesticide use or waste management, best practice can only minimise negative impacts. In these cases the positive part of the eco-rating scale will not be utilised and best practice will produce a score close to zero.

Individual eco-ratings have been derived for each farming activity including the use of inorganic and organic fertilisers, crop protection, resource management including energy and water efficiency, soil management, conservation and livestock management. Each eco-rating is related directly to the actions and practices which influence environmental impact, both positive and negative, within that activity area.

One of the driving criteria in the development of the system is that it had to be fully operational utilising only readily available farm data. Any other data would have to be stored in accessible databases. Two different methodologies were adopted.

Where reliable quantitative data are available on a field by field basis (e.g. fertiliser use, pesticide applications, lime use), these have been used to derive the performance index. The software uses application rates, parameters which affect the fate and transport of pollutants in the environment together with simple heuristical models to measure environmental performance. Where only less reliable data are available, or the data are qualitative or 'soft' then a checklist, multiple-choice audit has been developed and used. A range of options are provided from which the user must select those which apply or which describe their practices. These options range from ideal practice to very poor practice and each option has an associated score depending upon how far that option digresses from the 'minimal risk' situation. Scores within discrete activity areas are aggregated and normalised to a pre-defined scale $( \pm 100)$ to aid interpretation and transparency.

\section{VALIDATION AND PILOTING OF EMA}

Complete validation of any computer model, advisory system or other support system is impossible. Validation is normally intended to increase confidence in the system with respect to its ability to successfully carry out a task. If it succeeds then its credibility increases. Validating a tool such as that described here is quite problematic. The eco-ratings derived are highly site specific, dependant upon site conditions and actual farming practices, measuring hazards and increased risk arising from poor performance. Direct comparison of one situation or site with another is difficult. This software is basically an expert system, utilising a knowledge base which contains data sets describing ideal environmental practices. Unlike simulation models where model results can often be compared with hard numerical data, expert systems often utilise soft and fuzzy data and so can not be so easily validated, especially as experts themselves do not always agree. The best that can normally be done, therefore in a validation process, is to check that the conclusions and recommendations of the system broadly agree with the majority of expert thinking.

Piloting, evaluation and testing has been carried out on a variety of levels and is still on-going. This process includes:

- in-house alpha testing of the software for usability and performance assessment;

- demonstrations and hands-on workshops with farmers, their consultants and other experts;

- detailed discussions with experts in different fields. Various organisations have been involved in the development phase and have discussed the approach, provided advice and in many cases data and information.

- workshops and demonstrations arranged by interested organisations such as Farming and Wildlife Advisory Group (FWAG) and the Fertilisers Manufacturers Association (FMA). The software has been made available at a number of farmers workshops and training sessions looking at the software in relation to, for example, pesticides, nitrates and phosphates, Integrated Crop Management and waste management.

- one to one sessions with individual farmers. Farm visits were made to test the data, often using data directly from farm management software. Other farmers supplied data directly to the research team. It was then processed and the report returned to the farmer;

- beta testing involving Safeways Stores plc. The prototype system has been installed on the computers of their technical staff and made available to their growers on an individual basis and at special workshops. Farmers tested the system with their own data. 
These exercises generated a range of comments, ideas, and requests which have been incorporated into the system. A number of simple case studies are described below which have arisen from this evaluation process and serve to illustrate how the EMA system can be used.

\section{Fertiliser Use}

The principal environmental impacts arising from fertiliser use are the contamination of waterbodies with nitrate via leaching and phosphate due to run-off and the loss of gaseous ammonia and nitrous oxide contributing to acid rain and global warming. A rule-base has been developed based upon information collated from a variety of sources, including the MAFF Code of Practice for the Protection of Soil (1993) and the MAFF Fertiliser Recommendations (1994). These recommendations are based upon the economic optimum quantities of nutrients required by the crop depending upon soil type and soil nutrient reserves. Using a simple relative error calculation a base-line eco-rating $F_{N}$ for nitrogen is calculated using equation 1

$F_{N}=\left(\left(F_{R}-F_{A}\right) * / F_{R}\right) * \beta$

$F_{A}$ is actual field applications of nitrogen (inorganic fertilisers and organic manures). $F_{R}$ is the quantitative recommendations. $\beta$ is a scaling factor set to 20 .

As an example consider a field growing potatoes. The soil type is organic and the soil analysis gave an ADAS N soil index (MAFF, 1994) as 0, meaning that there was less than or equal to $120 \mathrm{mg} / \mathrm{l}$ available $\mathrm{N}$ in the soil. Fertiliser was applied in the seedbed at a rate of $220 \mathrm{~kg} / \mathrm{ha} \mathrm{N}$. No organic manures were applied. Recommendations state that for a yield of around $40 \mathrm{t} / \mathrm{ha}$ the crop required $180 \mathrm{~kg} / \mathrm{ha} \mathrm{N}$. Consequently an excess of nitrogen was applied and $F_{N}$ is calculated as -4.4 on a scale of \pm 100 .

This baseline eco-rating is then put into the context of the site looking at how that site and practices contribute towards the risk of nitrate leaching and phosphate loss. This is achieved by considering other factors such as application timing, rainfall, soil porosity, field size and the proximity of surface and groundwater's and scoring these depending upon their influence on the risk. This simplistically establishes a measure of environmental performance, closely linked to the environmental hazards the farming practices pose. The risk of losing phosphate is determined using a simple risk assessment approach using qualitative data considering the application method, practices such as minimal cultivation's, tillage and under sown crops, and the risk of soil erosion. The phosphate part of the assessment is only initiated if soil phosphate levels are above $70 \mathrm{mg} / \mathrm{l}, \mathrm{P}$ index above 5, as this is considered an environmental trigger value (Goulding \& Brooks, 1997), below which the risk of phosphate loss is minimal. A rule-base is used to store heuristical and best practice descriptions and using a scoring system $f(\mathrm{~A})$ is derived and added to the baseline ecoratings (equation 2)

$\mathrm{F}_{\mathrm{F}}=\mathrm{F}_{\mathrm{N}}+f(\mathrm{~A})$

A ball-park estimate of the potential nitrate leaching loss is determined using equation 3 . Heuristical rules have been used to derive scaling or risk factors for crops which have then be used to adjust the excess amount of $\mathrm{N}$ applied to the soil such that a simplistic reflection of the amount of nitrate likely to leach is estimated.

Many sophisticated models for estimating nitrate leaching exist (e.g. ABB, 1992) but these tend to be more suitable for scientists than for farmers themselves as they often require detailed input data. What is needed in a system such as EMA is a trend indicator, a simple guide to losses which are sensitive to farming practices.

$N_{\text {leaching potential }}=\left(\left(N_{\text {excess }}{ }^{*} \alpha\right)+\left(\beta^{*} S_{c}\right)\right) * S_{L}$

Where:

$\mathrm{N}_{\text {excess }}$ is the quantity of $\mathrm{N}$ applied over the recommendations

$\alpha$ is the general case (i.e. heuristical) loss i.e $80 \%$ of the excess $\mathrm{N}$ leaches in arable systems, $50 \%$ with other systems.

$\beta$ is the baseline leaching - some nitrate loss is always expected regardless of conditions, set at 35 $\mathrm{kg} \mathrm{N} / \mathrm{ha}$ for arable crops 
$\mathrm{S}_{\mathrm{c}}=$ crop factor e.g. grassland $=0.5$, winter cereal $=1.0$, spring cereal $=1.0$, irrigated potatoes $=2.0$, un-irrigated potatoes $=3.0$, vegetables with high $N$ inputs $(>200 \mathrm{~kg} / \mathrm{ha})=3.0$, peas and beans $=1.5$, Oilseed rape $=1.5$, sugar beet $=0.5$

$S_{L}=$ Land management factor e.g. catch or cover crop drilled before mid Sept $=0.3$, fields left in stubble or volunteers $=0.5$, early established grass $=0.5$, winter Oilseed Rape $=0.8$, Other crops $=$ 1.0 .

As an example consider a crop of winter barley (i.e. crop influencing leaching) on a sandy soil, $\mathrm{N}$ fertiliser applied was $175 \mathrm{~kg} / \mathrm{ha}, \mathrm{N}$ recommended were $160 \mathrm{~kg} / \mathrm{ha}$ (economic optimum).

From equation 3:

$$
\mathrm{N}_{\text {leaching }}=((15 * 0.8)+(35 * 1.0) * 1.0) \quad \text { Estimated Potential } \mathbf{N} \text { loss }=47 \mathrm{~kg} / \mathrm{ha}
$$

\section{Case study:}

A farm located in Essex is approximately 75 hectares in size of which 60 hectares is used for cropping via an arable rotation and the remaining 15 hectares is permanent grassland, woodlands, scrub and ponds. The soil type is a typical mineral soil over a boulder clay. The site does not overlay a principal aquifer, the annual rainfall is below average, there is no evidence of soil erosion and land management techniques do not encourage erosion or leaching. The data relating to four fields on the farm is given in Table 1. The software evaluation is given in Table 2.

\section{Table 1: Field data for fertilisers}

\begin{tabular}{|c|c|c|c|c|c|c|c|c|}
\hline $\begin{array}{l}\text { Field } \\
\text { Ref: }\end{array}$ & $\begin{array}{l}\text { Size } \\
\text { ha }\end{array}$ & Crop & $\begin{array}{l}\text { AD } \\
\mathbf{N}\end{array}$ & $\begin{array}{l}\text { Soi } \\
\text { P }\end{array}$ & $\begin{array}{l}\text { ces } \\
\mathrm{K}\end{array}$ & $\mathrm{N}$ applied & Timing & $\begin{array}{c}\mathbf{N} \\
\text { Recommendations }\end{array}$ \\
\hline 1 & 3.9 & Winter Wheat & 0 & 1 & 3 & $230 \mathrm{~kg} / \mathrm{ha}$ & $\begin{array}{l}\text { Split spring } \\
\text { dressing }\end{array}$ & 210 kg/ha \\
\hline 2 & 4.1 & Winter Wheat & 0 & 2 & 3 & $236 \mathrm{~kg} / \mathrm{ha}$ & $\begin{array}{l}\text { Split spring } \\
\text { dressing }\end{array}$ & $210 \mathrm{~kg} / \mathrm{ha}$ \\
\hline 3 & 3.0 & Winter Wheat & 0 & 3 & 3 & $236 \mathrm{~kg} / \mathrm{ha}$ & $\begin{array}{l}\text { Split spring } \\
\text { dressing }\end{array}$ & $210 \mathrm{~kg} / \mathrm{ha}$ \\
\hline 4 & 5.0 & $\begin{array}{c}\text { Winter } \\
\text { Oilseed Rape }\end{array}$ & 0 & 3 & 3 & $210 \mathrm{~kg} / \mathrm{ha}$ & $\begin{array}{l}\text { Split spring } \\
\text { dressing }\end{array}$ & $160 \mathrm{~kg} / \mathrm{ha}$ \\
\hline
\end{tabular}

\section{Table 2: Eco-rating data}

\begin{tabular}{|c|c|c|c|c|c|}
\hline Ref: & $\begin{array}{c}\text { Baseline } \\
\text { Eco-Rating } \\
\left(F_{\mathrm{N}}\right)\end{array}$ & $f(\mathbf{A})$ & $\begin{array}{c}\text { Field ER } \\
\left(\mathbf{F}_{\mathrm{F}}\right)\end{array}$ & $\begin{array}{c}\text { Potential N loss } \\
\text { via leaching }\end{array}$ & $\begin{array}{c}\text { Estimated } \\
\begin{array}{c}\text { Financial } \\
\text { Wastage } £\end{array}\end{array}$ \\
\hline 1 & -2 & +5 & +3 & $51.0 \mathrm{~kg} / \mathrm{ha}$ & $£ 23.40$ \\
\hline 2 & -3 & +6 & +3 & $55.8 \mathrm{~kg} / \mathrm{ha}$ & $£ 31.98$ \\
\hline 3 & -3 & +6 & +3 & $55.8 \mathrm{~kg} / \mathrm{ha}$ & $£ 23.40$ \\
\hline 4 & -7 & +1 & +1 & $92.5 \mathrm{~kg} / \mathrm{ha}$ & $£ 75.00$ \\
\hline Total & & & $+3($ acceptable $)$ & $\begin{array}{c}66.5 \mathrm{~kg} / \mathrm{ha}(\text { wt av. }) \\
1.1 \text { tonnes N across site }\end{array}$ & $£ 153.78$ \\
\hline
\end{tabular}

In this system eco-ratings between -20 and +20 are considered acceptable and equating to best practice. Scores above +20 would imply a very low environmental hazard arising for fertiliser practices. However, a high positive eco-rating would need to be looked at in conjunction with the eco-ratings derived for soil sustainability as the nitrogen soil levels may not be maintained if adequate nitrogen is not supplied. This would, over time, result in loss of soil fertility. In determining the eco-rating a leeway between that applied and that recommended is allowed before the performance rating is seriously penalised. This allows additional nutrients to be applied if a higher yield is required than that upon which the recommendations are based. However, an excess of greater than $40 \mathrm{~kg} / \mathrm{ha}$ is considered environmentally unacceptable.

The results obtained here show that practices are comparable to best practice. The additional amount of $\mathrm{N}$ applied were not overly excessive except, perhaps, on field 4 . Application timing were ideal ensuring that the $\mathrm{N}$ is available at the time the crop most requires it. Nitrate leaching is not likely to be overly excessive under the described conditions, the soil type not encouraging the problem and annual rainfall being below average. 
The financial wastage data has been calculated across all four fields by using a cost price of $£ 120$ per tonne of fertiliser which contains $40 \% \mathrm{~N}$. Whilst the total financial wastage is not huge in this case considering the farms profits (Net margin averaging at over $£ 400$ per hectare) of $£ 6,400$ across these fields, it does demonstrate that environmental protection need not be costly and in fact can increase farm profits.

\section{Pesticide Use for Crop Protection}

The pesticide eco-rating system has been described in detail in a previous papers (Lewis et al., 1997b). In summary equation 4 is used to derive the pesticide eco-rating. $P$ is determined for each pesticide applied to a specific field (f) and averaged to give a field value. Each field value is then weighted by field size and aggregated to give a whole-farm value for pesticide use.

$P_{f}=L R_{S E R}+\sum^{1-n}\left(E_{n} \cdot Q_{n}\right)$

where:

$L R_{S E R}$ is the eco-rating associated with the whole product. It is derived from the associated label precautions (LR) depending upon the site specific sensitive environmental receptors (SER) and from assessing regulatory compliance and impacts such as resistance.

$E_{n}$ is the sum of the scores derived in the evaluation the physico-chemical properties of each active ingredient $\mathrm{n}$ in the product and, therefore, the fate and transport and so potential impact on the environment.

$Q_{n}$ is the quantity of active ingredient applied to the field and $n$ is the number of active ingredients in the product formulation. The function $\left(E_{n} \cdot Q_{n}\right)$ is derived for each active ingredient (1 to $\mathrm{n})$ in the formulation and summed to provide a product total.

Various detailed examples are given in Lewis et al. (1997c). Additional examples based on actual farm data are given below:

As discussed earlier many researchers are looking at scoring and ranking the environmental impact of pesticides. Recently a Dutch methodology (Farmers Weekly, 1997) was applied to sugar beet herbicides. The technique determines 'pollution points' with respect to the risk to water, soil and groundwater. The results are given in Table 3 below, with them arranged in the authors perceived order of overall impact based on the awarded pollution points.

\section{Table 3: The Dutch method and sugar beet herbicides}

\begin{tabular}{|l|c|c|c|}
\multicolumn{1}{|c|}{ Herbicide } & Water & Soil & Groundwater \\
\hline lenacil & 230 & 46 & 41,000 \\
\hline triflusulfuron-methyl & 4 & 1 & 5,200 \\
\hline sethoxydim & 0 & 0 & 1,300 \\
\hline clopyralid & 0 & 0 & 550 \\
\hline chloridazon & 14 & 1 & 330 \\
\hline phenmedipham & 1 & 0 & 31 \\
\hline
\end{tabular}

The results for the same herbicides determined by EMA are given in Table 4 assuming best practice, complete regulatory compliance, the site lies over a principal aquifer and the field has surface water within $10 \mathrm{~m}$ of the boundary.

Table 4: EMA and sugar beet herbicides

\begin{tabular}{|l|c|}
\hline \multicolumn{1}{|c|}{ Herbicide } & Eco-ratings \% \\
\hline lenacil & -38 \\
\hline triflusulfuron-methyl & -26 \\
\hline phenmedipham & -22 \\
\hline chloridazon & -20 \\
\hline sethoxydim & -20 \\
\hline clopyralid & -14 \\
\hline
\end{tabular}


Both approaches indicate that lenacil is likely to lead to the most significant impacts, followed by triflusulfuron-methyl. At the lower impact end of the scale the two approaches do not produce precisely the same order but do indicate that, perhaps, there is little to choose between them.

\section{Case study:}

The farm in question has approximately 800 ha used for cropping. Winter wheat is the main crop (350 ha) however sugar beet (150 ha) and potatoes (100 ha) are also grown. The remaining area is dedicated to field vegetables particularly carrots and onions. The soil type is organic mineral over clay. The farm has a major reservoir used for supplying water for irrigation. There is also a small amount of woodland, setaside and permanent grasslands. Table 5 shows part of the crop protection spray programme applied to a sugar beet crop and the eco-ratings awarded.

\section{Table 5: Field data for pesticides}

\begin{tabular}{|l|l|l|l|l|l|l|l|}
\hline & $\begin{array}{l}\text { Active } \\
\text { Ingredients }\end{array}$ & $\begin{array}{l}\text { Pest/problem } \\
\text { treated }\end{array}$ & $\begin{array}{l}\text { Applicat- } \\
\text { ion rate } \\
\text { kg/ha }\end{array}$ & $\begin{array}{l}\text { Wind } \\
\text { speed } \\
\text { Force }\end{array}$ & $\begin{array}{l}\text { Application } \\
\text { timing }\end{array}$ & $\begin{array}{l}\text { Weather } \\
\text { conditions }\end{array}$ \\
\hline 1 & $\begin{array}{l}\text { fenpropidin+ } \\
\text { propiconazole }\end{array}$ & rust & 0.7 & 1 & Late March & warm \& sunny & $\begin{array}{l}\text { Eco- } \\
\text { ratings } \\
\text { poor }\end{array}$ \\
\hline 2 & $\begin{array}{l}\text { ethofumesate } \\
\text { phenmedipham }\end{array}$ & $\begin{array}{l}\text { annual } \\
\text { dicotyledons }\end{array}$ & 2.2 & 4 & Early May & cool \& cloudy & $\begin{array}{l}-67 \\
\text { Poor }\end{array}$ \\
\hline 3 & metamitron & $\begin{array}{l}\text { annual } \\
\text { dicotyledons }\end{array}$ & 1.1 & 4 & Early May & cool \& cloudy & $\begin{array}{l}-47 \\
\text { Poor }\end{array}$ \\
\hline 4 & metamitron & $\begin{array}{l}\text { annual } \\
\text { dicotyledons }\end{array}$ & 2.2 & 3 & Late May & cool \& cloudy & $\begin{array}{l}-75 \\
\text { Poor }\end{array}$ \\
\hline 5 & $\begin{array}{l}\text { ethofumesate+ } \\
\text { phenmedipham }\end{array}$ & $\begin{array}{l}\text { annual } \\
\text { dicotyledons }\end{array}$ & 2.2 & 1 & Late May & cool \& cloudy & $\begin{array}{l}-59 \\
\text { Poor }\end{array}$ \\
\hline 6 & $\begin{array}{l}\text { metamitron } \\
\text { annual } \\
\text { dicotyledons }\end{array}$ & 0.5 & 1 & Mid June & warm \& sunny & $\begin{array}{l}-28 \\
\text { Acceptable }\end{array}$ \\
\hline 7 & $\begin{array}{l}\text { cypermethrin } \\
\text { cutworms }\end{array}$ & 0.25 & 3 & Early July & warm \& cloudy & $\begin{array}{l}-25 \\
\text { Acceptable }\end{array}$ \\
\hline
\end{tabular}

The eco-rating of -100 for the first application shows very poor practice. This value was awarded as the pesticide (fenpropidin \& propiconazole) does not have approval under the Control of Pesticides Regulations 1986 (COPR) for sugar beet applications. It appears that this pesticide was applied to a neighbouring crop of winter wheat to treat rust for which COPR approval is in place. As there was evidence that the infection had spread to this field the spray programme had been extended: a common practice. Another problem identified is that the Code of Practice (MAFF \& HSC, 1990) advises against spraying under such weather conditions due to the increased risk of drift.

The differences between the eco-ratings derived for the two applications of ethofumesate and phenmedipham ( $2 \& 5)$ is due mainly to the more suitable windspeed during the latter application. The Code of Practice warms against spraying herbicides in winds higher than force 3 .

With respect to the three applications of metamitron $(3,4 \& 6)$, two main issues were identified. Firstly windspeeds were again not ideal. Secondly the multiple applications of the same pesticide over a relatively short period of around 6 weeks raises concerns regarding weed resistance to the pesticide developing. There is extensive evidence that weeds, world-wide, are becoming resistant to herbicides (Heap, 1996). Evidence also suggests that this process is encouraged with continuous and frequent applications of the same herbicide because the populations of resistant individuals increases as non-resistant individuals are killed. Consequently, future generations are more likely to be resistant. The individual eco-ratings are penalised because of these multiple applications. No problem was identified with application 7 , the eco-rating lies above the -40 nominal boundary and has COPR approval in place.

\section{Lime use}

Soil $\mathrm{pH}$ is critical for soil sustainability and for optimum crop yields. Most field crops grow well in a soil $\mathrm{pH}$ ranging from 6.0 to 8.0 and most cultivated soils have a pH between 5.5 and 7.5. However, if the soil is too acid i.e. $\mathrm{pH}$ is too low then some plants and crops may suffer restricted growth due to a reduction in the availability of nutrients (e.g. calcium, molybdenum, boron and magnesium) and due to an increase in levels of other elements (e.g. aluminium, iron and manganese) which are toxic at higher concentrations. In extreme cases of acidification soil structure may suffer and erosion can 
occur. However, if inappropriate lime applications are made and the soil becomes too alkaline then deficiencies of other trace elements such as copper, cobalt and selenium may occur which could adversely effect the growth of grazing livestock. In addition, the local eco-systems could be damaged, with the possibility of local species competing ineffectively with more vigorous species which thrive under the enforced conditions.

The assessment approach in EMA utilises the GENFER (ADAS, 1986) lime recommendations lookup table. Target soil pH levels are defined considering the crop to be grown and the soil type. For example arable rotations on a mineral soil would have a target $\mathrm{pH}$ of 6.5 whilst on a peaty soil the target $\mathrm{pH}$ is 5.8. The amount of lime required by the soil to raise the $\mathrm{pH}$ from its current level to the target can be determined using the "Lime factor". This is dependant upon the soil type and whether or not the rotation is principally arable or grass.

This calculation is based on ground limestone which is largely calcium carbonate, however various other materials can also be used for neutralisation. These include for example dolomitic limestone which is a mixture of calcium and magnesium carbonates, burnt lime (a commercial calcium oxide which also contains some magnesium oxide) and waste lime arising from the sugar beet and water industries. The neutralising capacity (NC) of the material can be referred to by comparing it to ground limestone (i.e. the amount of acid a given quantity of that material will neutralise when it is totally dissolved compared to the same quantity of ground limestone). For example if ground limestone has an $N C$ value of 1.0 then for dolomitic limestone $N C=1.1$, burnt lime $N C=1.74$, waste lime from the water industry $\mathrm{NC}=0.54$ and that from the sugar beet industry $\mathrm{NC}=0.54$. Consequently, the amount of lime which is actually applied to the field needs to be adjusted according to the neutralising value of the material used.

Within the system eco-ratings are assigned depending on the amount of lime being applied (t/ha) compared with recommendations. Other rules are also applied and scores suitably adjusted. For example the GENFER recommendations advise against applying more than 7 t/ha to grassland as damage to the crop may occur.

\section{Case Study:}

The farm in question is located in the north of England and has sandy top soil over a Permo-triassic sandstone aquifer. The soil is naturally deficient in lime with $\mathrm{pH}$ of the cultivated top $15 \mathrm{~cm}$ of the soil varying between 5.0 to 5.7. The fields are cropped in an arable rotation growing linseed and spring barley. The data for each field assessed and the derived eco-ratings are given in Table 6.

The target $\mathrm{pH}$ for each field is 6.5 (arable rotation on sandy soil).

On the first field 'Waters Edge', the soil pH is approaching the target $\mathrm{pH}$ and the linseed crop would probably have grown reasonably well without any liming although a maintenance dressing is probably advisable. The $\mathrm{pH}$ below which linseed growth may become restricted is quoted as 5.4. The amount of neutralising material applied is well in excess of what would be needed for maintenance and would have given a resultant $\mathrm{pH}$ in the order of 8 , close to the alkalinity boundary. Hence the poor eco-rating. The soil pH of Sunning North is sufficiently low at 5.1 to restrict growth of the linseed crop had no liming material been applied. Although an excess does appear to have been applied the result $\mathrm{pH}$ is acceptable at 7.4 and so an acceptable eco-rating has been awarded. On Sunning South the soil pH is again low enough to have caused growth problems to the Spring barley crop. Barley could become stunted on soils with a pH below 5.9. However, the lime application would have produced a pH around 7.6 which is beginning to get a little high. The Eco-rating awarded is just in the 'below acceptable' banding which begins below -20. On the final field, Jonnes Way, the application of liming material has resulted in a soil $\mathrm{pH}$ of around 7.3 which is perfectly acceptable.

Table 6: Field data for lime applications

\begin{tabular}{|c|c|c|c|c|c|c|}
\hline & pH & $\begin{array}{l}\text { Lime } \\
\text { applied t/ha }\end{array}$ & $\begin{array}{l}\text { Material } \\
\text { used }\end{array}$ & $\begin{array}{c}\text { Max. app. } \\
\text { t/ha }\end{array}$ & $\begin{array}{c}\text { Target } \\
\mathrm{pH}\end{array}$ & $\begin{array}{l}\text { Eco- rating } \\
0 /-100\end{array}$ \\
\hline Waters Edge & 5.7 & 8 & Burnt Lime & 8 & 6.5 & $\begin{array}{c}-34 \\
\text { Below acceptable }\end{array}$ \\
\hline Sunning North & 5.1 & 8 & Burnt Lime & 8 & 6.5 & $\begin{array}{c}-4 \\
\text { Acceptable }\end{array}$ \\
\hline Sunning South & 5.3 & 8 & Burnt Lime & 8 & 6.5 & $\begin{array}{c}-21 \\
\text { Below acceptable }\end{array}$ \\
\hline Jonnes Way & 5.0 & 8 & Burnt Lime & 8 & 6.5 & 0 \\
\hline
\end{tabular}




\begin{tabular}{|l|l|l|l|l|}
\hline & & & & Acceptable \\
\hline Site average & \multicolumn{2}{|c|}{} & -15 \\
& & Acceptable \\
\hline
\end{tabular}

\section{Livestock management}

The livestock audits within EMA cover the husbandry of poultry (layers and broilers), indoor and outdoor pigs, beef and dairy enterprises including the dairy parlour plus sheep and goats. Silage production is also included. In these audits the data required is essentially qualitative and utilises checklist style questionnaires. However some quantitative data is required for example stocking densities and space allocations to enable assessments of welfare to take place via direct comparisons with the welfare regulations.

\section{Case Study:}

The farm in question is situated in the St Albans area of Hertfordshire. It is a mixed farm which incorporates dairy, beef, sheep, indoor pigs with an arable and field vegetable operation. The farm has around 220 cattle overall which graze a total of twelve fields. The site has several large ponds and a small woodland together with permanent grassland. There are also hedgerows, ditches, public footpaths and bridleways and some artificial landscaped features. Shooting and fishing activities also take place on the site. The EMA software generated the following report shown in figure 1 based on the data and information supplied by the farmer:

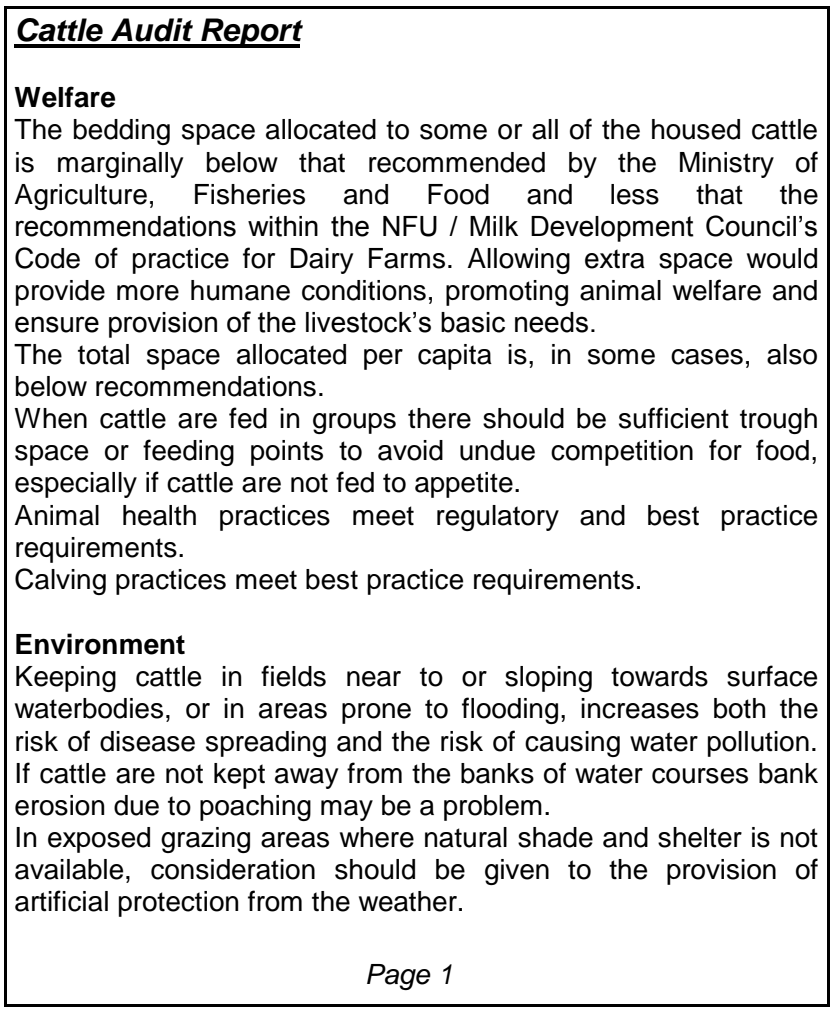

\section{Transportation}

Stringent laws exist concerning the transportation of cattle and other farm animals. Even if you give this responsibility to a haulier you must satisfy yourself that all regulations are met and ensure particular attention to standards of cleanliness, water and food requirements and exposure to weather. Also ensure there are adequate rest stops during long journeys

\section{Dairy Parlour}

Audit finds suggest that all dairy parlour practices meet requirements.

\section{Eco-ratings}

Cattle Eco-rating: $-17 \pm 100$ Acceptable

\section{Approximated emissions:}

$\begin{array}{ll}\text { Ammonia to air: } & 0.6 \mathrm{t} / \mathrm{yr} \\ \text { Methane from slurry: } & 15 \mathrm{t} / \mathrm{yr} \\ \text { Slurry: } & 637 \mathrm{t} / \mathrm{yr} \\ \text { FYM: } & 484 \mathrm{t} / \mathrm{yr}\end{array}$

Page 2

\section{Figure 1: Livestock Report}

The study showed that the practices carried out on the farm broadly complied with the regulations and with what is considered to be best practice. This is shown by the eco-ratings falling into the acceptable band (between -20 and +20 ). The main findings with respect to the cattle audit was that space allocations per capita were marginally less than recommended. Actual bedding space for the smaller sized animals $(<300 \mathrm{~kg}$ ) was stated as being 2 square metres whereby the Code recommends around 2.75 square metres. For the larger-sized animals ( $>800 \mathrm{~kg}$ ) actual space was given as 6 square metres per head where the Code recommends around 6.50. Total space for the larger animals was also found to be wanting (6 square metres rather than 8.70 ). 


\section{CONCLUSIONS}

The case studies reproduced here serve to show the scope and ability of the EMA software. Piloting and validation are still on-going with various organisations and farmers themselves. There has been no shortage of volunteers and the feed back process has helped to ensure that the software is simple to use, provides the type and level of information required and is not over demanding with respect to the input data required.

The software has been designed to run under WINDOWS 3.1 or 95 and ideally requires a Pentium processor. However, it will run, albeit a little slow, on lower specification machines. At the time of writing a dissemination study is underway to see how best the software can be introduced into the agricultural industry.

\section{ACKNOWLEDGEMENT}

The research project described here is funded by the UK's Ministry of Agriculture, Fisheries and Food and the Milk Development Council. It has been carried out in collaboration with ADAS and IACR-Rothamsted. The help and advice from the Ministry and from the many other organisations involved is gratefully acknowledged. The views expressed in this paper are those of the authors and not necessarily those of the sponsors.

\section{REFERENCES}

- AAB - Association of Applied Biologists (1992) Nitrate and Farming Systems In Aspects of Applied Biology no. 30

- ADAS (1986) GENFER Lime Recommendations Look-up Table

- Goulding, K. and Brooks, P. (1997) Phosphate Losses to Water, BBSRC Business 12-13

- Gustafson, D.I. (1989) Groundwater ubiquity score: a simple method for assessing pesticide leachability, Environmental Toxicology and Chemistry, 8: 339-357

- Farmers Weekly, Oct 1997 'Safer Scores for Pesticides' p64

- Heap, I.M. (1996) International Survey of Herbicide-Resistant Weeds. Annual Report

- Hornsby, A.G. (1992) Site-specific pesticide recommendations: the final step in environmental impact prevention. Weed Technology 6, 736-742

- ISO 14001 International Organisation for Standardisation (1994) Committee Draft ISO/CD 14001

- Lewis, K.A.; Newbold, M.J.; Skinner, J.A. and Bardon, K.S. (1996) A Decision Support System for Environmental Management of Agriculture. Conference Proceedings of Eco-Informa '96., Lake Buena Vista, Florida, USA

- Lewis, K.A.; Tzilivakis, J.; Skinner, J.A.; Finch, J.; Kaho, T.M.; Newbold, M.J. \& Bardon, K.S. (1997a) Scoring and Ranking Farmland Conservation Activities to Evaluate Environmental Performance and Encourage Sustainable Farming. Sustainable Development, 5, 71-77

- Lewis, K.A.; Newbold, M.J.; Hall, A.M. and Broom, C.E. (1997b) Eco-rating system for Optimizing Pesticide Use at Farm Level: Part 1: Theory and Development, The Journal of Agricultural Engineering Research. 68, 271-279

- Lewis, K.A.; Newbold, M.J. and Broom, C.E. (1997c) Eco-rating system for Optimizing Pesticide Use at Farm Level: Part 2: Evaluation, Examples and piloting, The Journal of Agricultural Engineering Research. 68, 281-289

- MAFF (Ministry of Agriculture, Fisheries and Food) (1993) The Code of Good Agricultural Practice for the Protection of Soil. MAFF Publications PB0617.

- MAFF (Ministry of Agriculture, Fisheries and Food) (1994) Fertiliser Recommendations for Agricultural and Horticultural Crops (RB209). MAFF Publications ISBN 0-11-242935-1

- MAFF \& HSC (1990) Pesticides: Code of Good Practice for the Safe Use of Pesticides on Farms and Holdings, HMSO, London

- Newbold, M.J.; Lewis, K.A.; Tzilivakis, J.; Finch, J.; Kaho, T.M.; Skinner, J.A. \& Bardon, K.S. (1997) The Options for Informal Environmental Management: The Agricultural Industry Highlighted. Ecomanagement and Auditing, 4:1, 22-27

- Reus, J.A.W.A. \& Pak, G.A. (1993) An environmental yardstick for pesticides. Med. Fac.

Landbouww. Univ. Gent 58/2a 249-255

- Skinner, J.A.; Lewis, K.A.; Bardon, K.S.; Tucker, P.; Catt, J.A. \& Chambers, B.J. (1997) An Overview of the Environmental Impacts of Agriculture in the UK. J. Env. Management, 50, 111-128

- Tucker, P.; Lewis, K.A. and Skinner, J.A. (1996) Environmental Management for Agriculture: an expert system approach. Eco-Management and Auditing, 3, 9-14 